\title{
Development of Environmental Friendly Rubberized Asphalt
}

\author{
Moe Aung Lwin, Lee Yang Pin Kelvin, Ho Nyok Yong, and Wang Xuechun
}

\begin{abstract}
Greenhouse gas emission from the construction of asphalt pavement affect the environment during the production and laying of hot mix asphalt which are carried out at high temperatures. Asphalt mixes be produced and compacted at about $20^{\circ} \mathrm{C}$ to $40^{\circ} \mathrm{C}$ lower than the corresponding hot mix asphalt mixes. The lower temperatures reduce greenhouse carbon emission and energy used. In Singapore, about 32,700 tonnes of scrap tyres were produced in 2016 and recycling rate is $91 \%$ [1]. The applications of the recycled scrap tires are typically low in economic value and some are disposed in landfills, caused environmental problems and there is limited land fill space in Singapore. To maximize the use of scrap tires, a previous study was conducted to evaluate the use of crumb rubber (processed from scrap tires) in asphalt mix. The results showed that the rubberized asphalt containing crumb rubber has high potential to be used in Singapore roads. This study is a continuation of the previous research work, and aims to investigate the use of warm mix technologies to reduce the production and compaction temperatures of rubberized asphalt, which the type is open-graded asphalt mix. Two types of bitumen, straight-run bitumen of penetration grade $60 / 70$ and polymer modified bitumen of performance grade PG76 were used as reference samples for comparison. Different types of warm mix additives were evaluated. The performance of the rubberized asphalt was determined based on various types of laboratory tests which include resilient modulus, Los Angeles abrasion loss, tensile strength ratio and dynamic creep tests.
\end{abstract}

Index Terms - rubberized asphalt.

\section{INTRODUCTION}

W arm Mix Asphalt (WMA) is a green product that is produced at lower temperatures while maintaining the workability required to be successfully placed. Energy efficiency is a practical and cost-effective mean of mitigating carbon dioxide emissions while sustaining economic development. As an open economy with no natural resources, Singapore is vulnerable to

M.A. Lwin is with the Samwoh Innovation Centre Pte Ltd. (e-mail: moeaung.lwin@samwoh.com.sg) Ltd.

L.Y.P. Kelvin is with the Samwoh Innovation Centre Pte

H.N. Yong is with the Samwoh Innovation Centre Pte Ltd. W. Xuechun is with the Samwoh Innovation Centre Pte Ltd. rising energy costs that can affect our economic competitiveness. It is therefore crucial that we take steps towards becoming more energy efficient. Although there are several different WMA technologies and products, the main function of the WMA additives is to lower the mixing and compaction temperatures of asphalt mixture.

In Singapore, about 32,700 tonnes of scrap tyres were produced in 2016 and recycling rate is 91\% [1]. The applications of the recycled scrap tires are typically low in economic value and some are disposed in landfills. To maximize the use of scrap tires, a previous study was conducted to evaluate the use of crumb rubber (processed from scrap tires) in asphalt mix and the study was based on both wet and dry mixing methods of crumb rubber in hot mix asphalt. Results showed that the crumb rubber has a high potential to be used in Singapore roads [2].

This study is a continuation of the previous research work. In this study, research was carried out to investigate the use of warm mix technology to reduce the production and compaction temperatures of rubberized asphalt with respect to an open-graded wearing course (OGW) which is commonly used for highways in Singapore. OGW test samples were prepared using 1) polymer modified bitumen of performance grade PG76 and 2 ) straight bitumen of penetration grade (Pen) $60 / 70$ as control samples in accordance with the specifications of the Singapore Land Transport Authority (LTA). Crumb rubber can generally be added to the asphalt mixture in two ways, namely, wet mixing method and dry mixing method. In the wet mixing method, crumb rubber was blended with bitumen at elevated temperature before mixing with aggregate. However, there are few issues associated with the wet method, such as strong smell emitted during pre-blending process and a special blending facility is required to mix the crumb rubber and bitumen. In the dry mixing method, crumb rubber was added directly together with bitumen and aggregate for mixing of asphalt mixture. The benefits of this method are good control of amount of crumb rubber in the mix as well as easy operation without the need of any special mixing facility. By comparing these two methods, dry method was adopted in this study.

There are numerous studies on the use of crumb rubber in hot mix asphalt mixture, and use of warm mix technologies for asphalting paving mixtures. But only few have studied the application of warm 
mix technologies to asphalt paving mixtures incorporating crumb rubber, where the studies were based on wet mixing method [3-6].

Warm mix technologies comprise foamed bitumen, chemicals, waxes, and organic additives or combinations. The purpose of use of WMA is to lower production and compaction temperatures of road paving asphalt mixtures. Warm mix asphalt can be produced and compacted at about $20^{\circ} \mathrm{C}$ to $40^{\circ} \mathrm{C}$ lower than the corresponding hot mix asphalt mixes. The lower temperatures reduce greenhouse carbon emission and energy used. In this study, production temperature of OGW mix with crumb rubber by dry method was reduced $30^{\circ} \mathrm{C}$ lower and compaction temperature was reduced $35^{\circ} \mathrm{C}$ lower compared to original $\mathrm{OGW}$ hot mix and crumb rubber incorporating OGW hot mix.

Three types of warm mix additives were evaluated in this study. Test samples were prepared with optimal binder content for each type of OGW mixes. The performance properties were evaluated by means of resilient modulus, Los Angeles abrasion loss, tensile strength ratio, and dynamic creep tests.

\section{MATERIALS}

Crushed granite aggregate was used for this study. Specifications for OGW mix is shown in Table I. Crumb rubber of size 10 mesh (passing 2mm) was used. Straight bitumen of Pen 60/70 and polymer modified bitumen of PG76 were used as control mixes. Bitumen properties for Pen 60/70 and PMB PG76 are shown in Table II.

Three types of commercially available warm mix additives were used, namely, amino-substance derivatives, wax-based, and polyethylene-based were used. These warm mix additives were found to reduce the viscosity of the bitumen which allows the asphalt mix to be mixed and compacted at a lower temperature, thus achieving the required density.

TABLE I

SPECIFICATION FOR OPEN GRADED WEARING COURSE (OGW)

\begin{tabular}{cc}
\hline [7] & \\
\hline BS Passing $(\mathrm{mm})$ & Percent Passing \\
\hline 19 & 100 \\
13.2 & $90-100$ \\
9.5 & $30-70$ \\
6.3 & $25-35$ \\
3.35 & $20-30$ \\
2.36 & $18-26$ \\
0.600 & $12-20$ \\
0.300 & $10-15$ \\
0.075 & $7-11$ \\
\% soluble binder (\% by weight of total & $5.0-6.0$ \\
Voids in mix (\%) & $7-9$ \\
\hline
\end{tabular}

TABLE II

PROPERTIES OF PEN 60/70 AND PG76 BINDER

\begin{tabular}{|c|c|c|}
\hline Type of tests & Pen $60 / 70$ & PG 76 \\
\hline Standard penetration at $25^{\circ} \mathrm{C}$ (ASTM D5), dmm & 61 & 50 \\
\hline Softening point (ASTM D36), ${ }^{\circ} \mathrm{C}$ & 47 & 81 \\
\hline Rotational viscosity at $135^{\circ} \mathrm{C}$ (ASTM D4402), mPa.s & 450 & 2400 \\
\hline Dynamic shear $\mathrm{G}^{*} / \sin \delta @ 76^{\circ} \mathrm{C}$ (AASHTO TP5), kPa & 0.32 & 1.98 \\
\hline (TFOT residue) mass loss (ASTM D1754), \% & 0.2 & 0.1 \\
\hline (TFOT residue) softening point (ASTM D36), ${ }^{\circ} \mathrm{C}$ & 51 & 74 \\
\hline TFOT residue G*/sin $\delta @ 76^{\circ} \mathrm{C}$ (AASHTO TP5), kPa & 0.71 & 2.80 \\
\hline
\end{tabular}

The OGW mixes were mixed and compacted at various temperatures, depending on the type of binder and the presence of crumb rubber as determined in the previous study [2]. Polymer modified bitumen PG76 has higher viscosity than straight bitumen Pen 60/70. Consequently, OGW mixes with PG76 were mixed at $180^{\circ} \mathrm{C}$ and compacted at $150^{\circ} \mathrm{C}$. OGW mixes with Pen $60 / 70$ bitumen were mixed at $150^{\circ} \mathrm{C}$ and compacted at $135^{\circ} \mathrm{C}$. OGW mixes incorporating crumb rubber, prepared with Pen $60 / 70$ and warm mix additives were mixed at $150^{\circ} \mathrm{C}$ and compacted at a lower temperature of $115^{\circ} \mathrm{C}$ according to the LTA WMA requirements [7].

\section{EXPERIMENTAL DESIGN}

Experimental design was carried out in two phases. First phase was to determine the WMA additive dosage amount. The effect of different dosage amount of each additive was analyzed and an appropriate mixing was chosen for this study. In second phase, test specimens were prepared with the respective optimal dosage level and then performance tests were conducted and the results were compared and analyzed.

A. Phase 1: Determination of optimal WMA additive dosage

OGW samples with crumb rubber were prepared with $1 \%$ crumb rubber by weight of total mix. Marshall Test samples containing the WMA 
additives were prepared according to ASTM D6926. The theoretical maximum specific gravity $\left(\mathrm{G}_{\mathrm{mm}}\right)$ was measured for each mix and the air voids were calculated. The Los Angeles abrasion machine was used for the Cantabro test according to the LTA specification required for OGW mixes. The samples before and after Cantabro tests were shown in Fig. 1.

TABLE III

MIX DESIGN FOR VARIOUS TEST SAMPLES

\begin{tabular}{lccc}
\hline Mix & $\begin{array}{l}\text { Crumb } \\
\text { rubber }\end{array}$ & Additive & Bitumen \\
\hline OGW PG76 & - & - & PG76 \\
\hline $\begin{array}{l}\text { OGW-Pen } \\
60 / 70\end{array}$ & - & - & Pen 60/70 \\
\hline
\end{tabular}

OGW-Pen

60/70 CR

\begin{tabular}{|c|c|c|c|}
\hline $\begin{array}{l}\text { OGW-Pen } \\
60 / 70 \text { CR-A }\end{array}$ & \multirow{3}{*}{$\begin{array}{c}1 \% \text { in } \\
\text { total } \\
\operatorname{mix}\end{array}$} & $\begin{array}{c}\text { Amino- } \\
\text { substance } \\
\text { derivatives }\end{array}$ & \multirow[t]{3}{*}{ Pen $60 / 70$} \\
\hline $\begin{array}{l}\text { OGW-Pen } \\
\text { 60/70 CR-W }\end{array}$ & & Wax-based & \\
\hline $\begin{array}{l}\text { OGW-Pen } \\
\text { 60/70 CR-P }\end{array}$ & & $\begin{array}{l}\text { Polyethylene- } \\
\text { based product }\end{array}$ & \\
\hline
\end{tabular}

The optimal additive dosage was selected based on air voids of $7 \%$ to $9 \%$ and Cantabro weight loss not more than 5\% according to the LTA specifications for OGW mix [7]. The results are shown in Table IV.

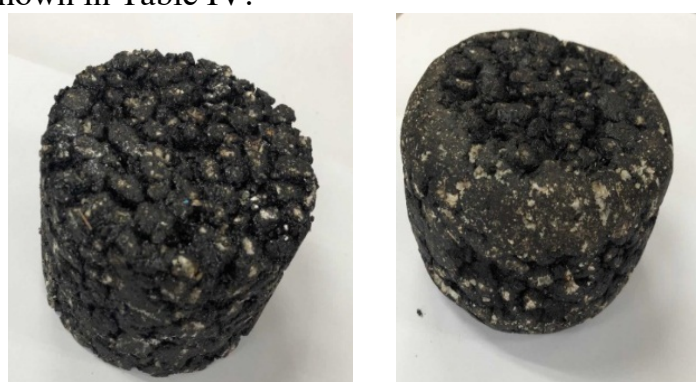

Fig 1. Cantabro test sample: left: before test and right: after test.
TABLE IV

RESULT FOR OGW MIXES WITH DIFFERENT VMA ADDITIVES AT OPTIMAL DOSAGE

\begin{tabular}{|c|c|c|c|c|c|}
\hline Mix & $\begin{array}{l}\text { Additiv } \\
\text { e Type }\end{array}$ & $\begin{array}{c}\text { Dosage (\% } \\
\text { by } \\
\text { bitumen } \\
\text { weight) }\end{array}$ & $\mathrm{G}_{\mathrm{mm}}$ & $\begin{array}{c}\text { Air } \\
\text { void, } \\
\%\end{array}$ & $\begin{array}{c}\text { Cantab } \\
\text { ro } \\
\text { Loss, } \\
\% \\
\end{array}$ \\
\hline $\begin{array}{l}\text { OGW- } \\
\text { Pen60/ } \\
70 \text { CR- } \\
\text { A }\end{array}$ & $\begin{array}{l}\text { Amino } \\
- \\
\text { substan } \\
\text { ce } \\
\text { derivati } \\
\text { ves }\end{array}$ & $1.5 \%$ & 2.363 & 7.48 & 3.94 \\
\hline $\begin{array}{l}\text { OGW- } \\
\text { Pen60/ } \\
70 \text { CR- } \\
\text { W }\end{array}$ & $\begin{array}{l}\text { Wax- } \\
\text { based }\end{array}$ & $6 \%$ & 2.368 & 7.14 & 3.45 \\
\hline $\begin{array}{l}\text { OGW- } \\
\text { Pen60/ } \\
70 \text { CR- } \\
\text { P }\end{array}$ & $\begin{array}{l}\text { Polyeth } \\
\text { ylene- } \\
\text { based }\end{array}$ & $6 \%$ & 2.351 & 8.33 & 3.77 \\
\hline
\end{tabular}

\section{B. Phase 2: Performance tests}

Marshall test samples were prepared at the selected additive dosages shown in Table IV for various performance tests as described in Table $\mathrm{V}$. Resilient modulus and dynamic creep modulus tests were carried out using a Universal Testing Machine (UTM-25), and indirect tensile strength for moisture sensitivity test was carried out with multispeed tester as shown in Fig. 1.

TABLE V

TyPe of ASPHALTIC CONCRETE TESTS

\begin{tabular}{|c|c|c|c|}
\hline Type of test & $\begin{array}{c}\text { Test } \\
\text { method }\end{array}$ & $\begin{array}{l}\text { No. of } \\
\text { samples } \\
\text { per test }\end{array}$ & Test purpose \\
\hline $\begin{array}{l}\text { Resilient } \\
\text { modulus test } \\
@ 25^{\circ} \mathrm{C}\end{array}$ & $\begin{array}{c}\text { ASTM } \\
\text { D4123 }\end{array}$ & 3 & $\begin{array}{c}\text { To evaluate the } \\
\text { stiffness of asphaltic } \\
\text { concrete }\end{array}$ \\
\hline $\begin{array}{l}\text { Moisture } \\
\text { sensitivity } \\
\text { test }\end{array}$ & $\begin{array}{l}\text { ASTM } \\
\text { D4867 }\end{array}$ & 6 & $\begin{array}{l}\text { To evaluate the } \\
\text { effect of moisture on } \\
\text { asphaltic concrete }\end{array}$ \\
\hline $\begin{array}{c}\text { Dynamic } \\
\text { creep test @ } \\
45^{\circ} \mathrm{C}\end{array}$ & $\begin{array}{c}\text { BS DD } \\
226\end{array}$ & 3 & $\begin{array}{l}\text { To evaluate the } \\
\text { resistance of } \\
\text { asphaltic concrete to } \\
\text { permanent } \\
\text { deformation }\end{array}$ \\
\hline
\end{tabular}




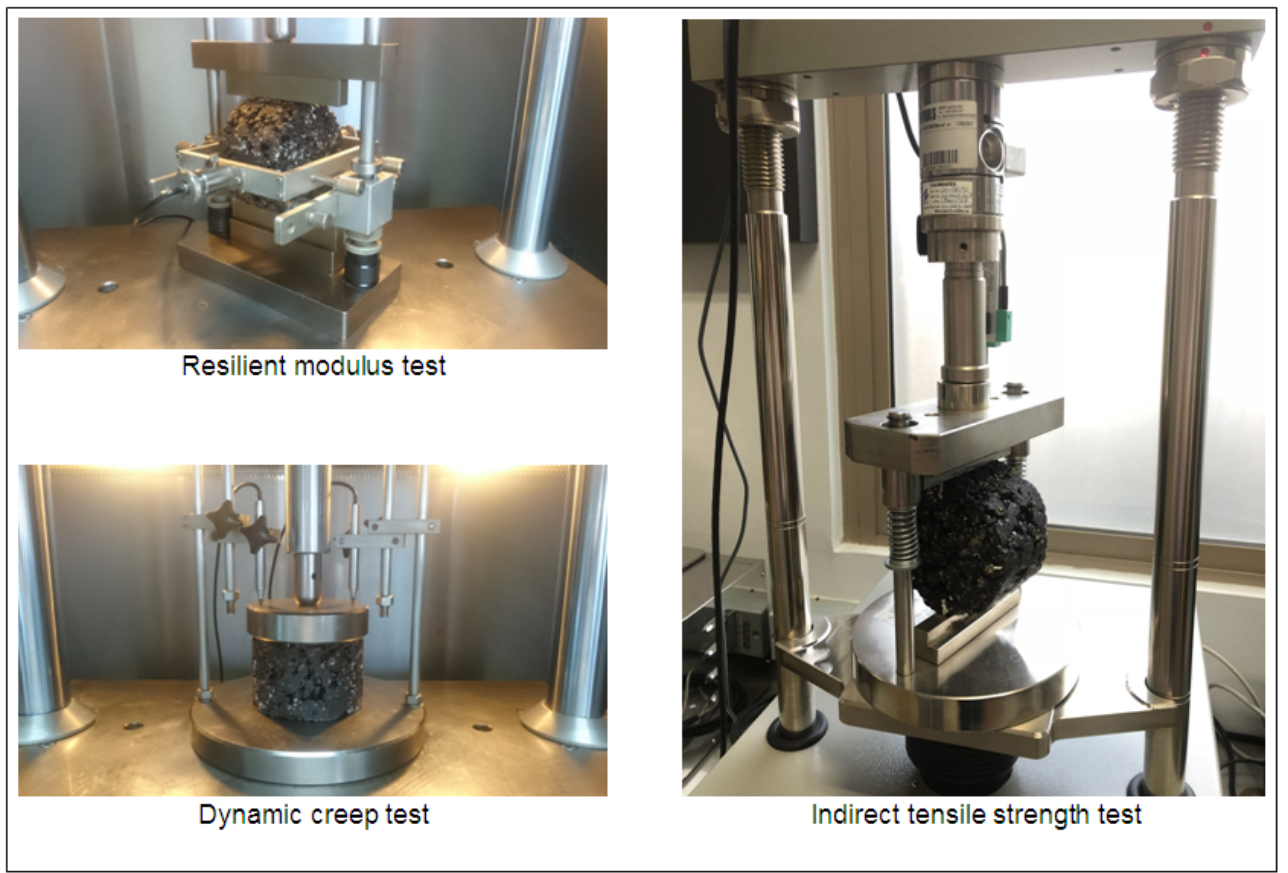

Fig. 2. Testing photos. 
1. Resilient modulus test

The resilient modulus test was conducted according to ASTM D4123 at $25^{\circ} \mathrm{C}$ at a loading frequency of $0.33 \mathrm{~Hz}$. Test was performed with haversine pattern which reflects the real loading of a moving wheel on the pavement. Among the rubberized OGW mixes, the resilient modulus of OGW-Pen 60/70 CR-A shows comparable resilient modulus value with control mixes. Results were shown in Table VI.

TABLE VI

RESILIENT MODULUS TEST RESUlTS

\begin{tabular}{lcccc} 
& \multicolumn{4}{c}{ Resilient Modulus (MPa) } \\
\hline & \multicolumn{4}{c}{ Type of sample } \\
\cline { 2 - 5 } & Sample 1 & Sample & Sample & Average \\
\hline OGW-PG76 & 2569.5 & 2514.5 & 2699.5 & 2594.5 \\
\hline OGW-Pen 60/70 & 2588.5 & 2710.4 & 2719.5 & 2672.8 \\
\hline $\begin{array}{l}\text { OGW-Pen 60/70 } \\
\text { CR }\end{array}$ & 3031.0 & 2775.5 & 3149.1 & 2985.2 \\
\hline $\begin{array}{l}\text { OGW-Pen 60/70 } \\
\text { CR - A }\end{array}$ & 2347.0 & 2469.1 & 2515.0 & 2443.7 \\
\hline $\begin{array}{l}\text { OGW-Pen 60/70 } \\
\text { CR - W }\end{array}$ & 1947.0 & 1870.9 & 1715.0 & 1844.3 \\
\hline $\begin{array}{l}\text { OGW-Pen 60/70 } \\
\text { CR - P }\end{array}$ & 1147.0 & 1234.5 & 1402.1 & 1261.2 \\
\hline
\end{tabular}

\section{Moisture sensitivity test}

Moisture sensitivity test measures the potential of asphalt mixture to moisture damage. Indirect tensile strength of 2 sets of compacted samples was tested. Each set contains 3 test samples. Set 1 was tested without conditioning and set 2 is subjected to vacuum saturation with water. Indirect tensile strength test was carried out according to ASTM D4867 on each sample and the indirect tensile strengths were compared as a ratio. Tensile strength ratio (TSR) was calculated by the equation as shown in equation (1). The results of indirect tensile strength and TSR values are shown in Table VII.

\begin{tabular}{lccc} 
TSR $(\%)=\frac{\text { Indirect tensile strength (moistured conditioned) }}{\text { Indirect tensile strength (unconditioned) }} \times 100$ & \\
\multicolumn{4}{c}{$\begin{array}{l}\text { TABLE VII } \\
\text { TSR RESULTS }\end{array}$} \\
\hline $\begin{array}{l}\text { Indirect tensile strength (kPa) } \\
\text { Type of sample }\end{array}$ & $\begin{array}{c}\text { TSR } \\
(\%)\end{array}$ \\
\cline { 2 - 3 } & $\begin{array}{c}\text { Moisture } \\
\text { conditioned }\end{array}$ & Unconditioned & \\
\hline OGW-PG76 & 910.3 & 946.6 & 96.2 \\
\hline OGW-Pen 60/70 & 741.2 & 781.4 & 94.9 \\
\hline $\begin{array}{l}\text { OGW-Pen 60/70 } \\
\text { CR }\end{array}$ & 1001.9 & 1044.3 & 95.9 \\
\hline $\begin{array}{l}\text { OGW-Pen 60/70 } \\
\text { CR-A }\end{array}$ & 693.8 & 833.2 & 83.3 \\
\hline $\begin{array}{l}\text { OGW-Pen 60/70 } \\
\text { CR-W }\end{array}$ & 565.7 & 654.2 & 86.5 \\
\hline $\begin{array}{l}\text { OGW-Pen 60/70 } \\
\text { CR-P }\end{array}$ & 438.3 & 482.4 \\
\hline
\end{tabular}

All the mixes have TSR values higher than $80 \%$ which is commonly accepted as the passing criteria for TSR test.
However, based on conditioned and unconditioned indirect tensile strength values, OGW-Pen 60/70 CR-A has comparable indirect tensile strength values to control mixes while OGW-Pen 60/70 CR-P has lowest indirect tensile strength values for both moisture-conditioned and unconditioned samples.

3. Dynamic creep test

The Dynamic creep test measures the resistance to permanent deformation subject to unconfined dynamic loading. The test was conducted according to BS DD 226 at $45^{\circ} \mathrm{C}$ at a loading frequency of $0.5 \mathrm{~Hz}$ for 1800 load cycles. The test results are shown in Table 8 . The results showed that both OGW-Pen 60/70 CR-W and OGW-Pen 60/70 CR-P have high dynamic creep modulus values which can provide more resistant to rutting under repeated loading.

TABLE VIII

DYNAMIC CREEP TEST RESULTS

\begin{tabular}{|c|c|c|c|c|}
\hline \multirow{2}{*}{$\begin{array}{l}\text { Type of } \\
\text { sample }\end{array}$} & \multicolumn{4}{|c|}{ Dynamic creep modulus (MPa) } \\
\hline & Sample 1 & Sample 1 & Sample 1 & Average \\
\hline OGW-PG76 & 19.2 & 18.6 & 21.9 & 19.9 \\
\hline $\begin{array}{l}\text { OGW-Pen } \\
60 / 70\end{array}$ & 8.7 & 10.3 & 8.6 & 9.2 \\
\hline $\begin{array}{l}\text { OGW-Pen } \\
60 / 70 \mathrm{CR}\end{array}$ & 12.8 & 14.1 & 12.7 & 13.2 \\
\hline $\begin{array}{l}\text { OGW-Pen } \\
\text { 60/70 CR-A }\end{array}$ & 8.9 & 7.1 & 7.4 & 7.8 \\
\hline $\begin{array}{l}\text { OGW-Pen } \\
60 / 70 \text { CR-W }\end{array}$ & 18.1 & 16.1 & 18.9 & 17.7 \\
\hline $\begin{array}{l}\text { OGW-Pen } \\
60 / 70 \text { CR-P }\end{array}$ & 20.1 & 16.9 & 18.5 & 18.5 \\
\hline
\end{tabular}

\section{Summary}

Based on the laboratory tests conducted, the rubberized warm OGW mixes prepared with the various WMA additives could achieve the required compaction density and Cantabro abrasion loss limit. However, the properties of the warm OGW mixes have varied performances.

For OGW-Pen 60/70 CR-A, the stiffness of the mix is comparable to OGW-PG76 mix but the mix has poor rutting resistance which reflects high potential of rutting deformation. In the case of OGW-Pen 60/70 CR-P and OGW-Pen 60/70 CR-W, both mixes showed good rutting resistance and lower stiffness. All mixes showed good resistance to moisture damage.

As compared to the hot mix OGW-Pen 60/70 CR, the warm mix rubberize asphalt mixes have lower stiffness and generally better rut resistance except for OGW-Pen 60/70 CRA. The lower stiffness could result in better fatigue performance which further study may be conducted for verification. In essence, this study demonstrated the potential use of warm mix rubberized asphalt mixtures in Singapore roads. 


\section{REFERENCES}

[1] National Environment Agency. NEA Waste and Recycling Statistics for 2016. http://www.nea.gov.sg/energy-waste/wastemanagement/waste-statistics-and-overall-recycling. Singapore

[2] H.N.Yong, L.Y. P. Kelvin and M.A. Lwin, "Recycling of Scrap Tires for Use in Asphalt Concrete in Singapore," MAIREPAV8, 2016.

[3] A. Smith. "Warm Mix Asphalt Rubber Concrete," Arizona Pavements/Materials Conference, 2009.

[4] D. Jones, R. Wu, C. Barros and J. Peterson," Research and Implementation of Rubberized Warm-Mix Asphalt in California," ISAP, 2012.

[5] A. Batari, M.Y. Aman, M. Saeed, T. Y. Ahmed and A. U. Chinade, "Rutting Assessment of Crumb Rubber Modifier Modified Warm Mix Asphalt Incorporating Warm Asphalt Additive," IRJET. 04, 2017.

[6] M.A. Bilema, M.Y Aman, N.A Hassan, K.A Ahmad, H.M Elghatas, A.A Radwan and A.S Shyaa, "Moisture Sensitivity of Crumb Rubber Modified Modifier Warm Mix Asphalt Additive for Two Different Compaction Temperatures," IOP Conf. Ser.: Earth and Environ. Sci. 140, 012072, 2018.

[7] Land Transport Authority, "Material \& Workmanship Specifications for Civil \& Structural Works," Infrastructure Design and Engineering Group Document. Singapore, 2017. 